\title{
IMPORTANCE OF COMMUNICATION IN COUNSELLING THE SPINAL CORD INJURY PATIENT
}

\author{
By Victor M. Santana Carlos \\ Centro de Medicina de Reabilitação, Alcoitão-Estoril, Estoril
}

Abstract. The purpose of this paper is to emphasise the value of counselling in the medical and vocational rehabilitation of the spinal cord injury patient in a world passing through a stage of deep and rapid evolution, and the importance that effective communication may have in it so that a better social integration or reintegration of the patient may be achieved.

Key words: Spinal cord injury patient; Counselling; Communication.

\section{Introduction}

THE considerable development in human sciences, particularly as regards interpersonal relations in the various types of communication, may be considered a manifest sign of a deep and rapid evolution-or should we call it revolution? - our society has been passing through, particularly in the last decade.

Contemporary society has gradually demanded a structural renovation of both the grass roots and the top levels. This society has anxiously tried to achieve a stable balance where, without detriment to the respect to which the human being is entitled, the individual may replace the social-a substitution which should be envisaged both for a society made up of small groups, as in the case of the family, and for the larger communities, whether national or international.

A knowledge of all these facts becomes important when we endeavour to rehabilitate the disabled so as to integrate them in the society for the building-up of which they can and should contribute. As we all know this object should be attained as far as possible through a process of total rehabilitation, i.e. one which takes into consideration the disabled and all his remaining potential, all his problems - physical, mental, social, economic and professional.

It is undoubtedly true that the integration or reintegration of the spinal cord injury patient in the community comes up against serious problems in a world where he has to work and live with at least a minimum of dignity. Among presentday problems in our world and which affect every human being, including the paralysed, unemployment looms large as an addition or as a sequel to them.

In fact, if we take into account the great changes that have occurred in the world at large and that the training made available to a given person (be he disabled or not) at a time of swift change as our own is no longer obtained as in times past, we are forced to go further than the mere 'training of persons for the functions they will discharge later' and be content with this. Even when this is so, at least to some extent, it should be borne in mind that, for instance, a young paraplegic will be trained for a profession which he may have to discharge from his 20 th year of age until retirement-in other words, over a period of time that may be as much as 40 years. This time-span is too long if we consider the ever greater advances of science and knowledge and their practical consequences. Thirty years ago no 
one would imagine that it would be possible to teach computer science in a school. And a little over 30 years ago no one could foresee the appearance of professions having to do with the exploitation of nuclear energy. No doubt that in a world in continuing change, what is particularly important is not so much to become adjusted, as the capacity for adjustment.

This is the reason why-apart from all that is basic and immanent in human nature and in the formation of the human person for a full discharge of the rights and duties-all the rest in teaching should be oriented towards a natural form of activity in evolution. 'It is possible', says Leprince-Ringuet 'to foresee accurately short-term techniques, say 5 years from now, but it is already highly uncertain when we look ahead Io years whether in the field of technology proper or as regards the number of technicians. Beyond IO or I5 years there is every probability of falling into error rather than otherwise'. Thus, when considering teaching or technical training programmes for the disabled in vocational training centres, or outside them, we should take these facts into account and try to avoid detrimental routines, undergo retraining from time to time in the form of more or less prolonged on-the-job training periods so as to bring our knowledge up to date, or eventually opt for a change in profession if circumstances render this advisable.

In connection with what was mentioned before, another important factor to take into consideration by all those engaged in the rehabilitation of the spinal cord injury patient, is the impact of environment and personality on disability. It is felt already during the process of medical and vocational rehabilitation but doubtlessly more so in the case of reintegration in the family, a job, or society generally. Man's ability to sustain himself as an independent individual on the basis of work, in spite of the impact an injury may have had in reducing or apparently destroying it, is often determined in the interplay between personality, environment and disease. However, the results obtained through exhaustive investigation, carried out by Dr Gudmund Harlem (I974), seem to confirm that disease-even when chronicis not the most important nor determinant of these factors. 'Impairments and social problems are connected' but it is not yet sufficiently clear what establishes this connection-a very important element to assess.

\section{Counselling the Disabled}

In the entire process of rehabilitation of the disabled and with a view to their more efficient integration to the community, counselling plays an eminent role in the team work.

Team work, as Joseph Stubbins (1967) righly points out, 'then becomes an interacting partnership or profession dealing with the fundamental needs of the patient as a whole person. To divide knowledge into separate fields is a matter of convenience. In fact there is a considerable amount of overlap. This overlapping of activities of the various members of a rehabilitation team should, however, contribute to stress or enhance the specific work of each team member and not, of course, to replace it. And it would be advisable for this to be so even when the criteria are not exactly the same. Mutual respect for other members of the team, plus an overriding interest in the client and his problems, should prevent differences of opinion from obstructing the team goal of optimum rehabilitation of the client.

In counselling the client, the objects to be attained are as a rule restricted, the focus being namely on the elimination of incapacitating symptoms or negative attitudes, though the counsellor will not cease trying to bring out and develop all 
the client's remaining potential. Non-acceptance of the disability, lack of cooperation of the client in one or another aspect of the prescribed rehabilitation programme, lack of will-power or motivation in starting the vocational training, and the desire to remain dependent on his relatives, are instances of frequent situations.

Nevertheless, the importance should be stressed of establishing limits of action in counselling the client. Both the counsellor and the patient should bear in mind that life cannot usually be changed. All one can do is just to change our own way of facing life and its problems. A good number of severely disabled clients, in fact, carry along with them complex problems which only indirectly have a bearing on the disability, or even have nothing whatever to do with it.

In any case the counsellor's help, though difficult, is indispensable to make it easier for the client to return to a productive type of life. This help is particularly necessary when the client's disability has a relation with his capacity for work which is not understood. 'The most difficult part of the counsellor's job is the achievement of permanent employment for his patient and in getting civic leaders' and businessmen's attention and cooperation to create job opportunities for the disabled.' We have here a challenge to the competence and dynamism of the counsellor in counselling not only the client, but also, quite often, the employers as well. This and other reasons should also stress the need for follow-up, that is 'keeping in contact with the patient once the agency services are over'.

\section{Communication in Counselling the Disabled}

Any hospital or rehabilitation centre is to a large extent judged through its staff, that is, through their professional competence and their possibilities of human contact. And in accordance with Stubbins, 'good teamwork requires good communication, not just reporting to the group and exchanging opinions. There is need for an awareness of the actions and interactions of the other professions with the patient, and a perceptiveness as to what observations will be useful to them. Team spirit, to which patients are extremely sensitive, is born of collaboration of all members of a competent team. If morale is high, it will be transmitted to the patient. It will spark in him the will to live and become proficient in living no matter what his handicap'.

Herein lies the reason why the actions and objectives of human relations, through well-conducted communication, will be all the more successful the better the active co-operation between all those who collaborate in the organisation, including volunteers or even visitors.

Communication thus may become a basically important element or an excellent opportnnity in counselling the patient. His reactions may, however, vary in accordance with the patient's age, temperament and/or mentality, and the type of injury. In this respect, Sir Ludwig Guttmann (1973) refers a very significant remark about the frame of mind of people meeting paraplegics: the case of a wounded priest-who wrote: 'One of the most difficult tasks of a paraplegic is to cheer up his visitors'. Often, it depends upon the manner of approach used by the doctor or any other member of the staff or visitors when communicating with the patient.

In fact the nature of communication will doubtlessly depend on information. This latter obviously suggests the idea of a transmitter which broadcasts in a more or less direct manner to a receiver. However, the idea of 'transmission' leaves the phenomenon of communication incomplete. According to Albou, the fundamental expression is that of reciprocity or, rather, of feedback: the individual is 
aware of the changes he produces in his interlocutor. His action is not executed independently of its effects, which are echced or feed back the act of communication. Reciprocity and role alternation are thus the essential traits of communication.

In its turn, information will depend a great deal on the informer, his intellectual, moral and technical qualities, the latter being viewed from the standpoint both of professional competence and of an adequate knowledge of human relations.

Besides the members of the rehabilitation team, the informer may be the patient, or even the public in general.

Frequently the patient may ask more or less anxiously for information in order to integrate his experience and feelings into a reality he can understand so as to be able to cope with the new situation. Or, when asking for information, he may be expressing concern about his future and that of his family. If he is not listened to and understood, it is quite possible that he will ask himself whether those who deal with his rehabilitation are sufficiently competent to treat him. Hence the great responsibilities of the entire personnel dealing with the total rehabilitation of the spinal cord injury patient entrusted to their care, and in particular the doctor and the rehabilitation officer (or rehabilitation counsellor). 'The counsellor', say Cull and Hutchinson (I975), is not expected to know everything, but he is expected to develop a genuine relationship. As with the other qualities, a lack of genuineness or accuracy of responding will impair the counsellor's progress'.

Verbal and non-verbal communication are of equal importance. From the tone of the counsellor's voice-which should be maintained at conversation level except when appropriately raised-the choice of words and the full attention given to the client instead of reading a folder, a report or a letter while the client is talking to the counsellor, a number of points should be carefully observed by the latter. Thus the counsellor must always control the interview because if he does not, if the roles played by the counsellor and the client were to be switched, counselling would cease. It is thus indispensable that throughout the interview the counsellor gives his best attitude of attention to the client, trying in the entire process of communication not only to listen to him, but also to hear and understand him. As Cull and Hutchinson (1975) quite rightly state, 'in counselling there is a vast difference between listening and hearing. Hearing implies a greater degree of understanding of what is being said than listening implies. The counsellor should therefore be aware of what the client is communicating on a more basic meaningful level.

According to Elsa L. Ramsden (I975), the professional should not attend to only part of the speaker's message. When a patient talks he also sends non-verbal messages which help the listener interpret the real meaning of the message. For 'the patient may say in words "I feel okay", but his non-verbal behaviour may indicate that, in fact, everything is not all right'. This clarification of the patient's message may reveal to us the various objectives he is pursuing through his words. Ramsden cites in this connection an example which is current in rehabilitation centres. Consider, for instance, this patient's words: 'Will I ever be able to walk again ?' 'The focus will be on ever with reference to time; or the focus may be on walk with the meaning related to the efficiency or normalcy of the walk.' In order to answer the right question it is, of course, important to determine the real meaning, whether by a greater stress on each of the words ever or walk by the patient, or bearing in mind not only the contents of the sentence but also the feeling communicated. The 'content' may be just a request for information about potential ability in ambulation, whereas the 'feeling' may be an expression of anxiety or fear that, indeed, he will not be able to walk again. 
The foregoing considerations allow us to foresee that successful counselling will depend a great deal on the ability to communicate. When learned and used with the highest and most balanced human interest, communication will undoubtedly be of the utmost value for better results in counselling the disabled.

\section{SUMMARY}

In the entire process of rehabilitation of the spinal cord injury patient, and with a view to a more efficient integration in the community, counselling plays an eminent role in the entire teamwork. Good counselling requires good communication. In its turn, communication is based on appropriate information, and the latter will depend a great deal on the informer, both his professional competence and adequate knowledge of human relations. Only thus will it become possible to contribute to authenticity in pyschological contacts, without which, whatever the means resorted to, there will be no true human communication and, therefore, the objective of counselling will not be attained.

\section{RÉSUMÉ}

$\mathrm{Au}$ cours du processus de la réadaptation totale du malade porteur d'une lésion vertebro-médulaire et en particulier en vue de son intégration communautaire les moyens à employer pour conseiller ou orienter la personne handicapée constituent un rôle important à jouer par les differents membres de l'équipe de travail. Bien conseiller demande une bonne communication. A son tour, la communication devra se baser sur une information correcte, celle-ci dependant beaucoup de la compétence professionnelle et d'une parfait connaissence des relations humaines de la part de celui qui informe. C'est seulment à cette condition qu'il sera possible de contribuer à une veritable authenticité dans les contacts psychologiques, sans quoi, quels que soient les moyens utilisés, il n'y aura pas une bonne communication humaine et, par conséquent, le but auquel on prétend parvenir, qui est conseiller le malade, ne sera pas atteint.

\section{ZUSAMMENFASSUNG}

Beim totalen Rehabilitationsprozess des spinalgeschädigten Kranken und besonders was seine vollwertige Einordnung in die Gemeinschaft betrifft, spielt gerade die Art der Beratung des Kranken von seiten jedes Einzelnen des Arbeitsteams eine äusserst wichtige Rolle. Gute Beratung setzt eine gute Kommunikationsgabe voraus. Auch soll die Kommunikation sich auf korrekte Information berufen, welch letztere sehr von der beruflichen Kempetenz und angemessenen Kenntnissen menschilcher Beziehungen des Beraters abhängt. Nur so können echte psychologische Kontakte herbeigeführt werden, ohne die-gleichgültig welche Mittel angewandt werden-keine wahre menschliche Kommunikation zustande kommt, also infolgedessen auch die angestrebten Ziele in der Beratung des Kranken nicht erreicht werden.

\section{REFERENCES}

Cull, J. G. \& Hutchinson, J. D. (1975). Techniques of counselling in the rehabilitation process. In J. G. Cull and R. E. Hardy (eds), Vocational Rehabilitation Profession and Process. Charles C. Thomas, Springfield, Illinois.

Guttmann, L. (1973). Spinal Cord Injuries: Comprehensive Management and Research, Chapter 29: Psychologic aspects. Blackwell Scientific Publications, Oxford.

HARLEM, G. (I974). The impact of environment and personality on disability. International Rehabilitation Review, Second Issue, New York.

Hostie, R. (1976). La communauté relation de personnes. Desclée de Brouwer, Paris.

LePrince-RINGUET, L. (1973). Science et Bonheur des hommes. Flammarion, Paris.

Mehrabian, A. (r97I). Silent Messages. Wadsworth Publishing Company, Belmont, California. 
RAMSDEN, E. L. (1975). The patient's right to know-implications for interpersonal communication processes. Physical Therapy Review, 55, No. 2.

SANTANA CARLOS, V. M. (1975). Communication in rehabilitation-a contribution for the social integration of the disabled. Paper presented at the International Seminar of the International Federation on Public Relations in Rehabilitation, Athens, I 975.

Stewart, M. (1975). The only patient without a visitor-so she paid. Letters, The Sunday Express, 28 Sept. 1975, London, England

STUBBINS, J. (I967). El consejero entrenado profesionalmente aporta una nueva dimension a la rehabilitacion. Reprinted from Revista Interaramericana de Psicologia, Vol. I, No. 2, Junio. 